\title{
1. Keynote Address - From Neo-Liberalism to the New Medievalism
}

\section{John Rapley}

In the autumn of 1950, a young man, the son of refugees from Nazi Germany, enrolled in the economics program at the University of Chicago. Chicago's department of economics was an unusual place in those days. Ever since the publication of John Maynard Keynes' General Theory in 1936, Keynesian economics - with its stress on the use of state intervention to manage economic development - had become more or less orthodoxy. Chicago stood against this trend, becoming something of a refuge for neoclassical economists. Neoclassical economics, with its faith in free markets, minimalist government and the ability of mathematical models to explain human behaviour, ran against the then-dominant consensus in Western economics, which believed that state management could ensure an economic growth rate that benefited owners and workers alike. Neoclassical theory tended to take a less sunny view of economic management, believing that there were costs in economic efficiency to redistribution. Among its most famous exponents, a fierce critic of Keynes who would go on to win the Nobel Prize in economics, was Milton Friedman.

Professor Friedman did not take well to his new student, whose name was Andre Gunder Frank. The feeling, by all accounts, was mutual. Professor Friedman's belief in free markets and respect for individual liberty, initiative and responsibility was evangelical. Frank, though, found Friedman's economics odious, especially since it tolerated and even justified inequality. The rebellious young doctoral candidate called for an economics that privileged equity over efficiency. So tense were Frank's relations with his mentors that he was asked to leave the department, though he returned quietly in 1957 to finish his dissertation.

Friedman developed much warmer ties to a set of Frank's classmates. In the 1950s, the University of Chicago and Chile's Catholic University signed an exchange agreement, funded by the Ford and Rockefeller Foundations and USAID, which was designed to facilitate the process of what was called 'ideological transfer'. Under this agreement, Chicago economists flew to Santiago to teach, while Chilean graduates received fellowships to study at Chicago. There, many of them gravitated towards the so-called money workshop put on by Professor Friedman. They came to hold him in much greater esteem than Frank had ever managed. Back in Chile, they came to be known as the 'Chicago Boys', libertarian economists in a time when Chile was moving ever further into a state-led and ultimately socialist economy. 
Frank's juxtaposition of equity and efficiency was, in fact, a fitting metaphor for the Cold War that was then being fought on many battlefields, Chile being but one. Arguably, from its earliest days at the start of the industrial age, what defined socialism had been its elevation of equality as a primary goal of human society. Not satisfied with the equality of rights that liberal theorists celebrated, socialists had always dreamed of creating a more equitable society in the allocation of resources. For economists, this created a difficult dilemma. It was long believed that inequality spurred savings and innovation, and gave people the restless appetite that drove work and accumulation. But if inequality was good for the economy, the lessons of 19th-century Europe showed that it could be bad for the polity. And an unstable political system, riven by conflicts between owners and workers, would eventually be bad for the economy.

For a while, Keynesian economics appeared to navigate a middle path between these two competing objectives - economic liberty and equality. Keynes had no particular love of socialism, and on the face of it did not concern himself with the matter of equity. Rather, his goal was to find a way to make capitalism more efficient. As it happened, though, that goal had the happy consequence of augmenting equity at the same time. Unlike the neoclassical economics that was still dominant in the Great Depression, Professor Keynes tended to see the operations of the demand side of economic equilibrium as most amenable to policy interventions. Thus, government policies that regulated demand could be used to manage the business cycle. In particular, fiscal policy, by redistributing wealth, could raise levels of demand and thereby prevent economies from sinking into recession.

The widespread adoption of Keynesian economic strategies in the West coincided with a rebound in economic growth that took hold about 1948, when the economic collapse occasioned by World War II bottomed out, and stability returned to Europe. The next quarter-century would see more or less continued economic expansion. So successful did Keynesianism seem to be that even conservative parties jettisoned their free-market thinking and warmed to the doctrine. Coinciding with the spread of demand management was the rapid expansion of welfare states in the West. In consequence, the age of the Keynesian welfare state did see income inequalities decline in the West. By the 1960s, the resultant perception - namely, that everyone was now a stakeholder in this system - led some scholars to speak of the end of ideology. Economists said recessions had been banished forever.

While income inequality declined in the industrial democracies, however, it remained greater than in the socialist economies. By 1948, of course, the socialist bloc had expanded quite dramatically from its early days after the Russian Revolution. Having liberated six East European countries from the Nazis, Moscow installed client regimes. In two other neighbouring countries - Albania and 
Yugoslavia - indigenous rebellions against Nazi occupation had brought communists to power. China had been swept by revolution. Korea would soon follow. Vietnam was seething.

While each of these countries would tinker with the model of socialist development, fundamentally, they all built their experiments on the same core principles. Markets, seen as the field on which exploitation occurred, were more or less abolished. Central planners were to allocate resources according to a rational design that met political goals. In short, politics would rule economics: the economy was to operate according to rational design, and reoriented to meet human needs. Or so it was supposed. The long and short of it was that prices, and wages, were fixed by the government. In consequence, large - immense, in the Soviet case - and centralised bureaucracies were built to allocate resources.

Despite the intellectual fashion today, which is to dismiss the socialist experiments as failed deviants, they did make accomplishments. Scientific development, particularly in the Soviet Union, reached heights that belied the largely undeveloped status of the underlying economies. At least in the earlier decades, growth rates were strong, even spectacular, as was the case for Russia in the 1930s. China, meanwhile, performed favourably compared with India. Of course, some of this can be attributed to a forcible raising of the savings rate, which required harsh, and at times even brutal, tactics.

Perhaps the most significant achievement of the socialist economies was to make marked strides towards reducing inequality. The Marxist dream of building a classless society never came to pass. Nevertheless, the measures of income distribution like the Gini Coefficient indicated that socialist states generally created more equitable societies than did their capitalist counterparts. The administrative fixing of salaries and wages, and the regulation of prices, ensured that a society's output could be distributed in such a way as to maximise the gains for those on the lower rungs of the economic ladder.

This equality did not come without a price. Efficiency was sacrificed on the egalitarian altar. Bureaucratically dictated prices did not always reflect true conditions of demand and supply. Surpluses and scarcities coexisted. When goods were cheaply available, what typically resulted were excesses of demand. What then followed was rationing or - that ubiquitous feature of the Soviet economy - queueing. Importantly, while central planning was generally up to the task of managing any resource-allocation that could be measured quantitatively, it struggled badly when it came to qualitative transformations. Bureaucrats could, for example, determine how many shoes should be produced in any given year, and mobilise the resources necessary to the task. But when it came to improving the quality of those shoes, it was an entirely different matter. The popular fascination with the West that came to characterise Russian 
culture by the 1980s apparently had less to do with a love of democracy than a desire for fashionable clothing, catchy music and cameras that didn't require more than one person to operate.

It is not that socialism was technologically backwards; far from it. The Soviet Union was remarkable in having built a powerful military-scientific complex atop what was, in large measure, still a resource-dependent Third-World economy. But if they could produce scientists and engineers as innovative as the Americans or Japanese, why could they not produce a more dynamic economy? The genius of American triumph in the Cold War indeed seemed to lie in the market economy. When the Pentagon wanted new military technology, it bought from private contractors, whose interest was in gaining the sale by raising their product quality. Once the product was developed, they could maximise their returns by privatising the technology. This served the Pentagon well, because to the extent that the firm recouped its costs through private sales, the price to the military dropped. Much of the technology we take for granted in our daily lives began its existence on the drawing boards of US defence contractors. In the Soviet Union, by contrast, control of information by the military prevented much technology being turned to civilian uses. The result was that the Soviet Union's military-scientific complex ended up bankrupting the economy. By the 1980s, the country's economy was going nowhere, at the very time that citizen demands were beginning to multiply.

Chile provided a vivid illustration of these advantages and disadvantages of socialism. Its income distribution on the eve of Salvador Allende's overthrow provided evidence of the egalitarianism of the socialist experiment. But its economy was beset by inefficiencies that sank it into crisis. Income distribution bought by printing money led to runaway inflation. Low returns on capital inhibited investment. This further exacerbated supply shortages, thereby worsening inflation. Restive workers, dissatisfied with the pace of change in Chile, repeatedly shut down plants, worsening productivity. By 1973, the economy was struggling badly. With or without US intervention, covert sabotage and a corporate campaign to end the socialist experiment, the Chilean economy was almost certainly doomed to continued crisis. The military intervention succeeded in no small measure because it was toppling an edifice that had already been teetering for some time.

Did the Chilean experiment in socialism fail? The answer really depends on whom you ask. One of Allende's economic advisers was in fact Frank, who joined the legion of leftist intellectuals flocking into Chile at its time of euphoria. Given that he had called for an economics of equity over efficiency, he could rightly point to the Chilean experiment as a success in social justice that was undone by capitalist intransigence and foreign meddling. 
But Frank was now a refugee once again, wandering the world looking for a new home. And the new wave of intellectuals flying into Chile took a different view. The Chicago Boys, many of whom stayed in exile during the Allende years, eagerly returned home. Once there, they quickly wormed their way into the junta that had been cobbled together to govern Chile. They then invited their old mentor, none other than Friedman, to fly in and lend his authority to their campaign to turn Chile from a socialist utopia into a neo-liberal one.

So radical a break with Chile's recent past did the Chicago Boys propose that Friedman, in a famous speech in Santiago, called it 'shock therapy'. The term would become almost mythical in the popular lexicon of the neo-liberal age. Friedman convinced his audience that a gradual approach to reforming the Chilean economy might well fail. The country had to make a radical break with its socialist past. Friedman so persuaded his audience, at the head of which sat the President, Augusto Pinochet, that within weeks his former students - the Chicago Boys - had taken over all the important economic ministries, as well as the Central Bank. Soon after Friedman flew back home to Chicago, the finance minister announced that the country would indeed begin its shock therapy.

From the late 1960s, governments had been experimenting with neoclassical policy remedies in various spheres of their economies. What made the Chilean experiment so bold was that it was, arguably, the first thoroughgoing neo-liberal transformation of a society. From top to bottom - via budget cuts, privatisations, mass lay-offs, deregulation, import liberalisation and the like - Chile reversed its socialist revolution. It was no simple task. Socialism had sunk deep roots in the country, and the junta decided to dig them right up and exterminate them. The process was brutal. And the economy struggled at first. But, by the 1980s, the painful restructuring had put the country back on a growth path.

One of Pinochet's earliest supporters had been a then little-known British politician named Margaret Thatcher. Recently elected as leader of Britain's Conservative Party, she heralded a whole new direction for Britain. Many wrote her off as hopelessly outside the mainstream of British politics. The traditional Toryism of her party accepted noblesse oblige as the price of a stratified society, and gradual decline as the inevitable future of a nation whose glories lay mostly in the past. Thatcher's commitment to individual liberty, responsibility and the entrepreneurial spirit made her an ideal neo-liberal. As she would always say, she gravitated to the thinking of Friedman, but only because his theories confirmed her deep-seated convictions.

About the same time Friedman was giving his Chilean lecture tour, Thatcher received a visit from an American. They had both heard of one another, but no more than that. When he paid his courtesy-call on his European tour, however, Ronald Reagan so engaged Thatcher that they struck up a friendship that would last the rest of his life. 
Within four years, of course, just as Chile was turning its economic corner, Thatcher was moving into Downing Street. The next year, she was toasting Reagan's victory in the US presidential election. The neo-liberal age, sown in a Chilean revolution, was now going into full bloom. Britain went through its own shock therapy of union-busting, fiscal austerity and monetary tightening. And just as Thatcher took on the coal miners, President Reagan signalled his determination to end union power when he crushed a strike by American air traffic controllers.

The years that followed saw one Western country after another turn towards neo-liberalism. Most often, this was done without electoral shock waves. Sometimes, right-wing governments moved further right. Everywhere, left-wing parties began to leave behind their socialist heritage as they opted for a 'third way' or 'new middle'. Arguably, the last stand of Keynesianism in the developed world took place in France. The French had bucked the Thatcher-Reagan tide by electing an old-fashioned socialist, François Mitterrand, to the presidency in 1981. France, like Britain and the USA, was wrestling with a deep recession. But while the British and Americans were trying neo-liberal therapy, France opted for an old-fashioned treatment: a Keynesian reflation strategy based on a program of heavy government spending. It produced a tremendous fillip ... to German industry. The situation in France failed to improve and, in 1983, the French socialists threw up their hands and caved in to the neo-liberal revolution. It was, in the industrial world, the last great stand of Keynesian economics.

That same recession was, in all likelihood, the turning point across the world. Having been put on the agenda of the industrial democracies by disgruntled voters who had lost faith in Keynesian politicians, neo-liberalism would now be placed on the global agenda by the global economic slowdown. Why?

To understand, we need to back up a few years. In the same year that Allende was overthrown in Chile, 1973, the modern world experienced its first oil shock. Incidentally, this shock, by inducing a major recession in the industrial countries, brought an end to the 'golden age' of growth that had until then made Keynesianism seem so triumphant. The failure of governing elites to find a lasting response to the resultant economic crisis is what brought on the crisis of confidence in Keynesianism. In this context, neo-liberal politicians such as Thatcher found a receptive audience with their promise of new solutions to what was, apparently, a new problem.

Be that as it may, the effect of the oil shock was to flood the bank accounts of Persian Gulf governments with dollars (the currency used to settle oil contracts on world markets). This money was recirculated through the Western banking system, which meant the world's major banks now had more money than they knew what to do with. But because they were paying interest on those deposits, they had to find someone to borrow the money in a hurry. They found receptive 
clients in Third-World governments, who faced the opportunity of obtaining credit at bargain-basement prices. If, instead of locking into long-term rates, they opted for variable-rate loans, they could bring their real rates of interest down to zero. The lure was irresistible.

On the face of it, it was perfectly sensible. Problems arose only in 1979, when the Iranian Revolution sent the Shah into exile and withdrew Iranian oil from the world market. Prices again surged. Once more, the Western economies went into recession. But this time, rather than try to reflate their economies with Keynesian stimulus packages, Western governments opted for a different approach. After all, as evidenced by the British and American elections, they were starting to come under new management. Rather than tackle the slump in demand, they chose to target the surge of inflation. Choking off demand with tight monetary policies - which in practice meant high interest rates - became the order of the day.

Here, then, was the situation: the world economy was in recession as a result of the oil shock. Demand for primary exports suffered particularly badly, driving down commodity prices. Obviously, Third World countries suffered the most. But it got worse: having run up their debts after the first oil shock, they now had to pay them back at surging rates of interest. It got still worse: the high interest rates in the USA drove up demand for the dollar, as foreigners chased the high returns on US savings accounts. And since the loans had to be repaid in dollars, Third-World governments had to set aside even more of their own earnings to buy loans. It was a perfect storm: developing countries saw their revenues plunge just as their expenditures soared. The bank was going to bust.

That is why Third-World governments had no choice but to turn to the IMF and World Bank to beg assistance. And assistance came with strings attached. The IMF has always been a neo-liberal institution; that is its mandate. But the World Bank had only recently come under the influence of neo-liberalism, and that was because Reagan had placed one of his allies in its presidency when he came to office. The long and short of it is that, during the 1980s, governments across Africa and Latin America found themselves moving inexorably, reluctantly onto the neo-liberal road.

But the real high-water mark of neo-liberalism came, arguably, in the 1990s. That is when most of the Middle East began to adopt neo-liberal strategies. Very importantly, India, after a decade of piecemeal and largely symbolic reforms, shifted determinedly towards neo-liberalism. Democratisation in Latin America consolidated the neo-liberal drift. And importantly — very importantly socialism fell.

In fact, socialism had been falling for a good while. In China, it had been doing so quietly since the mid-1970s. In the autumn of 1973, shortly after the overthrow of Allende, the Chinese Communist Party, following its own logic, rehabilitated 
Deng Xiaoping after his exile of the Cultural Revolution. Deng embodied the pragmatism of the faction in the party that was concerned that mainland China was falling behind Taiwan and Hong Kong in the development race. If there was to be any hope of Beijing one day retaking control of her renegade province, she had to do better economically. Within a couple of years, economic reform was on Beijing's agenda. By the end of the decade - as it happened, about the same time that Thatcher came to office - China began her long, transformative experience with economic reform.

Elsewhere, socialism was struggling badly by the 1980s. Despite the occasional revolution here or there, socialism's apparent global advance had stalled. Nowhere were socialist economies particularly healthy, for the reasons discussed earlier. The Soviet Union tried its hand at reform in the 1980s, but the inept handling of the process did not provide a new impetus, as happened in China. Instead, the economy all but collapsed. In the process, Moscow signalled to her east European allies that she could no longer subsidise them. There followed the dramatic autumn of 1989, where one East European government after another collapsed. The message to the Soviet Union's remaining client states in the Third World was clear: you are on your own. Some, such as Vietnam, Mozambique and, eventually, Angola, pragmatically reformed. Others, such as Ethiopia, broke up, as abandoned old friends fled into exile.

Thus, by the 1990s, as US-trained economists flew into Warsaw and Moscow to advise governments on how to implement their own brands of shock therapy, neo-liberalism was pretty much the only game in town. First-World countries no longer had to fight communism. Now, they tailored their aid policies to push reluctant governments towards free markets. In the Pacific region, neo-liberalism made its first appearance, arguably, after the 1987 Fiji coup. As Stewart Firth has shown, however, policy changes in Australia (in 1994) and the European Union (in 1996) prodded governments to adopt neo-liberal reform packages if they wished to continue benefiting from aid arrangements. The last hold-outs to neo-liberalism were the East and South-East Asian countries. There, capitalist economies had been managed by interventionist states, a model dismissed by American policy-makers as 'crony capitalism'. But when this model went into crisis in 1997-98, a new set of governments found themselves having to approach the IMF for rescue packages. And the IMF, which at that moment depended on the US Treasury for its financing, ended up passing on the recommendations of the Treasury Department in its aid stipulations. And, despite the pro-poor rhetoric of the Clinton Administration, the Treasury Department at that time was pursuing an aggressive neo-liberal agenda. By the end of the 20th century, therefore, in a dramatic quarter-century, most of the world's countries had shifted from state-led development to free markets. 
That is a whirlwind tour of the neo-liberal age. But why speak of it in the past tense? Is the neo-liberal age finished? Surely, to judge from the ubiquity of neo-liberalism, reports of its death would seem greatly exaggerated.

This is where the debate gets really interesting. On one side, neo-liberal triumphalists tell us that the world is flat and that neo-liberal globalisation is a force of nature that only Luddites dare resist. But, on the other hand, each time people of their ilk try to get together to celebrate their victory, they are dogged by thousands of protesters who say globalisation is dead. Who is right?

The correct answer probably lies somewhere in between. We have not entered a new age. We have, however, exited the old one, making this something of an interregnum. And I would suggest that the symbolic date on which the neo-liberal age ended was September 11, 2001, the date the command structure of history's most powerful empire was temporarily decapitated by a handful of men armed with box-cutters - conveniently, as it happens, also 28 years to the day after the overthrow of Salvador Allende.

To explain this cut-off point for the neo-liberal age, we need first to draw up a balance sheet of this period in history. The range of experience is vast, the issues complex, the data highly variable, mixed and often difficult to compare. Nevertheless, broadly speaking, one can arguably sum up the historical record by saying that, as a very general rule, neo-liberalism ushered in an age of faster growth, but rising inequality. Growth manifested itself most strongly in the 1990s, at least until the Asian Crisis of 1997-98. Obviously, not all countries benefited equally from neo-liberal reforms, but defenders of neo-liberalism can often fairly say that where reforms yielded sub-optimal results, it might have been because they were inadequately or improperly applied. Equally, critics of neo-liberalism often fail to give adequate attention to the problem of the counterfactual. Simply pointing to poor economic performance that coexists with neo-liberal reforms does not in itself indict neo-liberalism very strongly. In many countries, a plausible case can be made that economic performance was going to be bad, owing to pre-existing factors (themselves often the legacy of the sort of statist development policies sometimes held up as an alternative to neo-liberalism), and that what neo-liberal reforms succeeded in doing was arresting or at least mitigating contraction.

Arguably, therefore, the aggregate data acquit neo-liberalism on the count of failing to deliver growth. It is in translating that growth into an equitable distribution that neo-liberalism comes off badly. Once again, in painting on such a broad canvas, the perils of generalisation must be acknowledged. But there is now a good pool of anecdotal evidence, which appears to be corroborated by statistical surveys of the developed countries, which, taken together, make it reasonable to conclude that more often than not, neo-liberal reform has led to a widening of the income gap. 
So, Friedman was right: the attempt to create egalitarian societies was bad for growth. But then, Frank was right as well: neo-liberalism's singleminded focus on growth was bad for equality. Which one matters more?

Again, the answer depends on whom you ask. Neo-liberals, who see individuals as essentially asocial and rational utility-maximisers, reckon that people use themselves as reference points. If that's the case, it follows that if we are richer this year than the last, we must therefore be happier. And since the aggregate data suggest that most of the planet's citizens are, in fact, richer than they were a generation ago, why all this apparent unhappiness with the neo-liberal age?

The answer might lie, at least in part, in social psychology. Humans, after all, are social animals. As a result, they are more likely to use not themselves, but their peer groups, as reference points. If you and your neighbour no longer need to ride the bus, but own your own cars, you might still not feel better off if your friend is driving a Lexus while you are stuck with a Corolla. Inequality thus matters. Indeed, while the subject remains controversial, there is a good body of evidence that suggests that in a situation of rising inequality, political instability will augment even when incomes are rising across the board.

But there is more to it than just that. This rise in inequality has occurred at the same time that the State has - so to speak - retreated. In truth, there are but a few countries where the State has actually reduced its share of total economic expenditure. In a couple of countries - Somalia comes readily to mind, as does Afghanistan - there is, for all intents and purposes, no longer a central government. But, by and large, reports of the death of the State have proved greatly exaggerated. The difficulty is that a stationary state is, in relative terms, a slowly retreating one. Nowhere is this more the case than in the Third World.

This is because of a phenomenon so tectonic, we scarcely notice it: urbanisation. In the history of humankind, few revolutions can match it in scale and impact. After spending millennia close to the land that provided them with their sustenance, humans began a massive migration to the cities. It started two centuries ago, and picked up speed in the 20th century when Third-World cities began growing at unprecedented rates. In the next generation, for the first time in history, more humans will live in cities than rural areas. The nation-state, which was built atop urban economies, expanded to provide the wide range of cities people once provided in their own communities. So, where public expenditure fails to keep up with the growth of cities, problems can arise as citizens begin to look for new political patrons.

One of the first warning signs of this came back in the 1970s. Iran's oil-rich economy was booming in the wake of the first oil shock. As it did so, Tehran exploded, going from what had once been a provincial backwater to a major world city. But despite its immense resources, the Government could not keep up with the basic demands of all these citizens for water, housing, roads and 
security. Into this breach stepped Islamist organisations, raising funds from charitable donations and creating a virtual state within a state. This provided the basis of operations for the very movements that would later bring down the Shah.

Today, in much of the Third World, we are seeing similar developments. The competition for resources is played out on a field whose traditional arbiter the State - lacks the largesse needed to buy the loyalty of an ever-increasing number of players. As a result, on the sidelines, and sometimes even in the centre of the field, new huddles form as those who can 'deliver the goods' buy supporters.

Sometimes, as happened in Iran, this starts with legitimate groups. Islamic charities have played an important role in several Middle Eastern countries. Groups with less benign agendas, however, can often penetrate the networks established for legitimate purposes in order to pursue their own goals. An instance of this can be found in al Qaeda, the metonym for the amorphous global network of terrorist organisations that operates through legitimate channels of communication throughout the Muslim world.

Other times, the goals have illegitimate purposes from the start. Transnational criminal organisations have taken advantage of the explosion in demand for their services - drugs, money laundering, human trafficking. They have operated along the legitimate vectors of communication established in the global age, which thus made it easy to escape detection. They have sometimes formed opportunistic alliances with transnational terrorist organisations. And, in many cases, they have built up vast pools of resources. They have then used some of these to create virtual states within states in many Third-World cities (and sometimes in rural areas as well).

Where the State can no longer provide employment, build houses, pave roads or police the streets, or where the police are so woefully underpaid that they supplement their incomes from corruption, sometimes turning on the very citizens they are meant to protect, in such cases, private armies and mini-states might fill the vacuum left behind by a retreating state. A former senior officer in Jamaica's police force once said it well, when he lamented that the war on drugs that the USA wanted him to fight - and for which purpose it had then loaned him some helicopters - was 'unwinnable'. For in whole stretches of downtown Kingston, the children were being fed, clothed and schooled by drug money, and nobody was going to bite the hand that fed them. He knew who the gang members were, could arrest them all tonight and bring them before judges in the morning. But nobody would testify against them.

Indeed, in some Kingston communities, the Jamaican State is all but absent. Gunmen patrol the streets. There is a legal system, replete with 'courts' and even, in some cases, 'defence attorneys'. There is a rudimentary welfare system. 
And it all works fairly well. So it goes in other Third-World cities, from Rio de Janeiro to Lagos.

The State has not, however, disappeared. State retreat is not the same as state failure. Ineffectual though they might have become at times, these countries still maintain armies, police forces, bureaucracies and court systems. When they have to, governments can send their troops in with force majeure, as Nigeria does periodically to discipline wayward regional movements. What results is a struggle over turf, one that sometimes becomes quite violent. And state agents end up having to cooperate with private agents, whether it is policemen negotiating with gunmen or politicians meeting with criminal leaders to try to work out peace deals.

So, we have neither a strong state nor anarchy. Instead, what is emerging in many Third World countries is a phenomenon sometimes called the new medievalism. This emergent form of political system is so-called because it is characterised by overlapping and multiple authorities. Sovereignty is now, at best, negotiated. Rather than mere decentralisation, what we are seeing is the emergence of autonomous political agents, equipped with their own resource bases, which make them resistant to a reimposition of centralised control, giving them the power they need to interpenetrate with the state.

With one or two possible exceptions - highly decentralised federations such as Canada and Belgium could conceivably slide into neo-medievalism at some point in the future, though neither scenario seems very likely - the new medievalism is essentially confined to the developing world. It is rural and urban. Large stretches of the Andes, of the tropical rainforest in the Democratic Republic of Congo, of the borderlands separating Pakistan from Afghanistan, and of Afghanistan itself, could be seen to be governed within neo-medieval frameworks. Perhaps the future of neo-medievalism lies within the burgeoning cities of the Third World; those which, as nodes integrated into the global economy, standing often in the vanguard of global trends, are most likely to intensify the thrust towards the new medievalism. Cities such as Rio de Janeiro, Kingston, Lagos, and Mexican cities on the US border - these and many others arguably have portions that have seceded from the nation-state without constituting themselves as independent entities.

These communities are more than just states within states. They represent a new kind of state. Moreover, given their implication in the global economy, and their linkages to global cities in the First World that serve as access points to the markets their criminal enterprises serve, they are injecting manifestations of their organisation into the rich countries. Thus, for instance, gang warfare or apparently random murders in Toronto or London that seem senseless and anarchic within the context of those societies take on a new, brutally rational meaning when analysed within the context of the activities of gangs back in 
Jamaica or Nigeria (or Russia, or Albania, or a host of other countries). We might not be seeing the new medievalism in the developed countries. The transnationalisation of crime is not new. Nor are backward linkages to homelands that generate the criminal organisations. But what might be novel is the increasing difficulty of prosecuting criminals - whether they be terrorists or criminals who can find shelter in communities that have constituted themselves as largely autonomous entities.

Because it is not quite anarchy, some have taken a rather sanguine attitude to the new medievalism. Perhaps, they say, it might even be a new form of politics; a postmodern politics, in which traditionally oppressed groups have liberated themselves from oppressive states - as in Iraq, where the possible future break-up of a country might be bad for the nationalist project, but good for historically oppressed Shi'ites and Kurds. Moreover, in some places, the new medievalism might be quite benign. In much of sub-Saharan Africa, the reassertion of autonomy by sub-national agents in the face of state retreat reveals just how limited the penetration of the nation-state was in these societies. A new medievalism might, in some places, be a political system more appropriate to the needs of these societies. In short, it is possible to imagine a new medievalism that is not all bad.

Nevertheless, as many of us know all too well, neo-medievalist tendencies can also herald more troubling scenarios. There is always the danger that the process of reconfiguration might not end at the Middle Ages. It might go further back, to a sort of Dark Ages, as happened in Rwanda during its genocide, or the former Yugoslavia in its civil war, or — dare one say it? - the Solomon Islands. There is a subtext to the new medievalism: just as the original medievalism was built atop the triumph of German tribes over the Roman Empire, the new medievalism can itself degenerate into a cold, ruthless struggle for resources. This, of course, is happening in a context where abundance has never been greater, but relative scarcities never more acute.

Does all this mean that we face an inevitable future of declining states, a resurgent barbarism and a clash of civilisations? Not necessarily. The future will undoubtedly be challenging. But, as every economics freshman realises, risks and returns vary in equal proportions. In this case, the dangers and opportunities lie side by side.

The global economic landscape has been transformed by China's dramatic reinsertion into the global economy, and its likely return to the centre of the global political economy (at least in terms of gross output). We are only just beginning to feel the effects of this change, and they are already profound. Her booming industries are flooding world markets with finished goods. Her ravenous appetite for inputs has driven up demand for primary commodities. With prices on manufactured goods declining, and those on primary goods rising, we have 
entered an unusual conjuncture, the type of which the world economy has not seen in a very long time: the terms of trade have shifted, if only temporarily, in favour of developing countries.

Add to this the likelihood that the bias in global capital flows will favour developing countries in the next few years. After the Asian Crisis, four-fifths of the planet's savings pool flowed into one country, the USA. There, it inflated bubbles in stock, then bonds, then property markets. As each of these reached their limits, the direction of investment began to gradually move back in favour of developing countries. Barring major exogenous shocks, or a sharp downward correction in US financial markets as financial capital gradually moves in a new direction - if any of these eventualities occurred, they would quickly reverberate around the world - there are grounds for cautious optimism that the premium on investment in the Third World will decline, making capital more readily available.

Conceivably, therefore, big opportunities lie ahead. But all is not rosy. China's relatively vast labour reserve has so depressed global wages that the conventional path to Third-World development - proceeding through labour-intensive manufacturing, to skilled manufacturing, and then to services - the sort of route Singapore or South Korea followed, is probably now an extinct option. Likely trends in future trade deals are likely to confirm this. And, as the experience of Pacific Islands can attest, being forced to compete with China in the assembly of low-end products - textiles come rapidly to mind - is a prescription for economic failure.

Therefore, we truly have entered a new age. Future development models will have to draw on new blueprints, which in some cases will probably require a frog-leap over the industrial age and into an information-based one. But the capital expenditure needed for this sort of transition will probably demand a capital transfer on a scale even greater than private markets, despite their new-found optimism over 'emerging markets', might be able to mobilise. Global challenges will require global solutions. Are we up to it?

It is a lot to hope for. Still, it might not be an impossible dream. One of the things September 11 drove home was that the new medievalism would — as surely as the old medievalism defeated Rome - bring an end to any present-day 'empires'. Nodes in the world economy are intimately linked by formal vectors of communication. Pockets of opulence live beside seas of poverty. Geographical distance has been annihilated. When you can log onto the Internet and easily see - and practically experience - how the 'other half lives', the notion that worlds are really apart begins to tumble. Resentment grows. It festers. And it can move along those very vectors of communication, to deliver drugs, dirty money, bombs, or indeed the bodies that will carry them. 
The metaphor of my policeman is apt. It will not be enough for anyone to fight a war on terror. It will have no more chance of success than did his war on drugs. Until the children are fed, clothed and schooled on money earned in the formal economy, at levels that give the citizens of this planet a reason to 'buy into' the system, and to pay taxes to the State that will provide them with decent security, the war will remain unwinnable. Slowly, that reality seems to be seeping into the world's consciousness: that, like it or not, we will either rise together, or sink back as one into a new Middle Ages. There is no assurance of either eventuality. But it is certain that we do live in a fascinating age. 